\title{
Effective Leadership: The Panacea to Effective Teaching and Learning in Schools, Post Corvid -19
}

\author{
Dr. Solomon A. Boateng ${ }^{*} \quad$ Ruth Donkoh ${ }^{2}$ \\ 1.Springfield Public Schools, Main Street, Springfield MA, USA \\ 2.School of Educational Economics and Management, Zhengzhou University, China \\ *E-mail of the corresponding author: solosogh@yahoo.com
}

\begin{abstract}
It is not an understatement to mention that the recent Covid-19 pandemic has thrown world economies into anarchy and turmoil. As a result, unprecedented changes had to be made by the way teaching and learning is conducted in academic institutions around the world. Almost all educational institutions worldwide have pivoted to online learning in a bid to curb the spread of the virus. This sad turn of events has put undue pressure on educators to learn 21 st century technology skills to instruct successfully. This paper examines the need for innovative skilled leadership for effective transition to online teaching and improving teaching and learning.
\end{abstract}

Keywords: Innovative Leadership, Online Learning, Effective Planning, Pivot, pandemic, Organizational Culture. DOI: $10.7176 / \mathrm{JEP} / 11-33-01$

Publication date: November $30^{\text {th }} 2020$

\section{Introduction}

The Covid-19 pandemic has disrupted education world-wide and has fundamentally changed the way teaching and learning is conducted. According to a report by UNESCO in 2020, the pandemic caused the closure of schools all over the world and the devastating impact on students has been very overwhelming. Educational institutions had to pivot, innovate, and switch to online learning to ensure that the needs of students are met. Such drastic changes demand effective and innovative leaders who understand the value and dynamics of effective planning and implementation. In the wake of such unprecedented and unforeseen circumstances, effective leadership is required to change the current sad situation.

This paper discusses some important factors that education leaders should consider when transitioning to full online instruction in response to the global coronavirus pandemic. Effective leadership is paramount in leading this transition. According to Bates and Sangra (2011), some factors to consider when moving courses fully online include policy and planning, organizational culture, financial management and student engagement. Effective leadership, and each of these considerations, will now be explored briefly.

\section{Effective Leadership}

Leading organizational change in uncertain times such as this demands effective leadership. Clay (2010) asserted that effective leaders are the ones who are bold to take risk and learn to act. He further intimated that confidence is key for effective leadership to achieve set goals and implement change. Finally, Clay (2010) argued that the effective leader who implement change is one who is open-minded and willing to explore and apply new ideas. Indeed, for any school change effort to be successful, the role of the school administrator through every stage of implementation is critical. The attitudes and actions of school leaders surrounding new technologies will encourage and support teachers as they engage in learning opportunities and explore new tools. Through their role as school leaders, school administrators can help ensure that the use of technology is prioritized, and that teachers feel comfortable trying new things (Staples et al., 2005; Zorfass, 2001). According to Warrick (2011), there is a need for effective leadership to manage change amidst scarce resources to meet organizational needs. Fullan (2011) emphasized that skilled leaders focus on developing excellent relationships with students, staff, faculty and other stakeholders during uncertain times such as a pandemic.

In any institutional change effort, the role of the school administrator through every stage of implementation is crucial. The actions of school leaders surrounding new technologies will certainly encourage teachers as they engage in learning opportunities and explore new tools

\section{Organizational Leadership and School Culture}

An essential complement to effective school leadership is a school culture that encourages change. Educational institutions with successful educational interventions have organizational structures that promote teacher autonomy and effective collaboration among staff (Billig et al., 2005). These structures allow teachers to make ample time for collaborative work (Elmore, 1996). The school leader plays a valuable role as a motivator and role model and strives to build a school culture where teachers collaborate and work together towards a shared vision for change (Glazer et al., 2005). Additionally, it is incumbent upon the school leader to ensure that teachers have the support required and adequate technology tools connected to teaching practice and curriculum (Staples, A., 
Pugach, M.C., \&amp; Himes, D. 2005).

\section{Policy and Strategic Planning}

Carney (2010) defined a policy as a fundamental rule or law that govern our operations and, for that matter, our lives. Education policy, however, is the collection of legislation, rules, and regulations that govern how school systems and the people within them operate. In school systems, good policy enables good practice on the part of teachers. In higher education, researchers usually set a policy after a problem has been outlined and possible solutions recommended. Policymaking in higher education is very challenging as it is mainly dependent on the government and socio-political issues, which are constantly evolving and changing (Cibulka, and Cooper, 2015).

Bates and Sangra (2011) argued that policy and planning are crucial for effective online distance learning. Effective leaders should adopt credible and effective policies to govern educational systems and promote teaching and learning. Educational policy and planning comprise of policies such as staff and student training, student services, and other programs (Levy \& Beaulieu 2003). The majority of these policies should be aligned with the organization's mission and vision and should be geared towards achieving organizational goals. According to Casanova and Price (2018) anytime a policy like online learning is integrated into the institution's policies, it is easily adopted and embraced by all stakeholders. Therefore, educational leadership should be proactive and innovative by coming out with swift policies that meet the demand of the time.

Strategic planning tools are designed to aid institutions in implementing changes in a way that stakeholders can understand and sustain over time. With the current global pandemic, many educational institutions continue to make significant changes that require the use of strategic planning tools. Among many tools, one of the most popular used strategies is SWOT (Han, Hua, and Ma. 2015). Gantz (2001) defined strategic planning as a process by which the leadership of an institution determines what is intended for the future, and to put plans in place to get where it envisages to reach, in relation to its growth.

\section{Financial Management}

The prudent financial management of any organization is important for the growth and advancement of the entity. It is worthy to note that financial management impacts educational organizations, non for profit and all other businesses in both the private and public sector. According to Obrenovic, Du, Godinic, Tsoy, Muhammad Aamir, and Jakhongirov (2020) the forecast of the World Trade Organization predicts global trade volume could plummet from $12.9 \%$ to $31.9 \%$, while the International Monetary Fund (IMF) predicts that the global economy is expected to shrink by $3 \%$ in 2020 . It is therefore imperative that organizations prudently manage their meagre resources to meet the demands of their respective organizations, especially in times of crises such as the recent Covid-19 pandemic. Ušpurienè, Sakalauskas, and Dumskis, (2017) intimated that financial management accountability processes in every department of education involves the functions of management: planning, organizing, leading, and controlling. Almost all educational departments need adequate resources to meet their daily obligations and achieve set goals.

\section{Student Engagement}

The act of efficiently engaging students during uncertain times online is crucial for effective teaching and learning. The Covid-19 pandemic has prompted all educational institutions to abruptly switch to online learning. This sudden change has prompted and forced educators to adapt to the new norm and online teaching to meet the needs of all students. Indeed, technology continues to improve the ordinary course of business and education fundamentally, students need proficiency in digital, visual, and information technology skills to be active participants in the 21st-century world. (Brown, R. A., \& amp; Brown, J. W. 2010). According to Dixon (2010) educators must utilize multiple instructional techniques to effectively improve teaching and learning online. Kearns (2012) argued that asynchronous and synchronous communication means, can be utilized in the online platform. Asynchronous communication allows the transmission of information that can be viewed and responded to at any moment of time, as per the participant's convenience. Such means of interaction comprise emails, chat lists, discussion forums/boards, blogs, announcements, shared documents, virtual board, video tutorials and instant messaging (Kearns, 2012). On the other hand, synchronous communication takes place in real-time and participants must be logged online at the same time.

\section{Conclusion}

To sum up, financial leaders are the ones expected to be equipped with proper skills and training when it comes to budget development, analysis, and execution. In times like these, Covid-19 pandemic, all education leaders must lead by example and get everyone on board to achieve set goals. Also, financial leaders are acknowledged of the possible expenses that might be incurred and paid during budget development and budget execution. Education leaders must lead prudently and effectively supervise budget allocation, as budgeting requires extreme caution, focus, and discipline as it will serve as the foundation of the institution's operations and activities (Vohwinkle, 


\section{References}

Bates, A. W., \& Sangra, A. (2011). Managing Technology in Higher Education: Strategies for transforming teaching and learning. San Francisco, CA: Jossey-Bass Higher and Adult Education Series.

Brown, R. A., \&amp; Brown, J. W. (2010). What is Technology Education? A Review of the "Official Curriculum". Clearing House, 83(2), 49-53. DOI:10.1080/00098650903505449

Casanova, D., \& Price, L. (2018). Moving towards sustainable policy and practice-a five level framework for online learning sustainability. Canadian Journal of Learning and Technology/La revue Canadienne de l'apprentissage et de la technologie, 44(3).

Clay, Brett (2010) "Six Characteristics of Highly Effective Change leaders" Retrieved from http://www.innovationexcellence.com/blog/2010/08/20/six-characteristics-of-highly-effective-changeleaders/

Dixson, M.D., (2010). Creating effective student engagement in online courses: What do student find engaging? Journal of the Scholarship of Teaching and Learning, 10(2), pp.1-13.

Elmore, R. F. (1996). Getting to scale with good educational practice. Harvard Educational Review, 66(1), 1-26.

Fullan, M. (2011). The Six Secrets of Change: What the best leaders do to help their organizations survive and thrive. San Francisco, CA: Jossey-Bass.

Gantz, Emily M. (2001) Strategic planning: \&quote; A Ten Step Guide\&quot; Retrieved from http//: www.sitresources.worldbank.org

Glazer, E., Hannafin, M. J., \&amp; Song, L. (2005). Promoting technology integration through collaborative apprenticeship. Educational Technology Research and Development ,53(4), 57-67.

Obrenovic, B., Du, J., Godinic, D., Tsoy, D., Muhammad Aamir, S. K., \& Jakhongirov, I. (2020). Sustaining enterprise operations and productivity during the COVID-19 pandemic: "Enterprise effectiveness and sustainability model". Sustainability, 12(15), 5981. doi: http://dx.doi.org/10.3390/su12155981

Staples, A., Pugach, M.C., \&amp; Himes, D. (2005). Rethinking the technology integration challenge: Cases from three urban elementary schools. Journal of Research on Technology in Education, 37(3), 285-311.

Levy, S., \& Beaulieu, R. (2003). Online distance learning among the California Community Colleges: Looking at the planning and implementation. American Journal of Distance Education, 17(4), 207- 220. doi: 10.1207/s15389286ajde1704_2

Ušpurienè, A., Sakalauskas, L., \& Dumskis, V. (2017). Financial resource allocation in higher education. Informatics in Education, 16(2), 289-300. doi: http://dx.doi.org/10.15388/infedu.2017.14

UNESCO (2020). Education: From disruption to recovery (retrieved from https://en.unesco.org/covid19/ educationresponse).

Vohwinkle, J. (2016). Everything You Need to Know about Budgeting. Retrieved from https://www.thebalance.com/budgeting-101-1289589

Warrick, D. D. (2011). The urgent need for skilled transformational leaders: Integrating transformational leadership and organization development. Journal of Leadership, Accountability and Ethics, 8(5), 11-26.

Zorfass, J. (2001). Sustaining a curriculum innovation: cases of Make It Happen! In J. 